Vol. 3, No. 1, 2020

M. V. Shpariy, V. L. Starchevskyy, Vol. V. Reutskyy, Y. M. Hrynchuk

lviv Polytechnic National University,

Department of physical, analytical and general chemistry

e-mail: vstarchevskyy@gmail.com

\title{
STABILIZER FOR THE CATALYTIC SYSTEM OF THE DIRECT CHLORINE PROCESSING OF ETHYLENE TO 1,2-DICHLORETHANE
}

https://doi.org/

Article is devoted to the research of the influence of the sodium salt of perfluoro sulfonic acid, as a stabilizer, on the catalytic activity of iron chloride and sodium chloride in the reaction of direct chlorination of ethylene to 1,2- dychloroethane. During research authors found that increase of stabilizer concentration up to $4 \%$ mas. had no significant impact on the catalytic activity of the complex but increase from $4 \%$ mas. up to $10 \%$ mas. allowed to shorten time of dissolution of sodium chloride and to reach needed concentration of sodium ions in the reactor of direct chlorination. With research stabilizer concentration the purity of the formed dichloroethane increases and the amount of by-product - trichloroethane decreases.

Key words: direct chlorination, ethylene, 1,2- dichloroethane, perfluoro sulfonic acid, stabilizer.

\section{Introduction}

1,2-dichloroethane (DCE) is one of the multitonnage products of basic organic synthesis and is obtained mainly by the reaction of ethylene direct chlorination. For the processes of direct chlorination of ethylene in DCE are used Lewis type catalysts, namely: aprotic acids $\mathrm{FeCl}_{2}, \mathrm{FeCl}_{3}, \mathrm{SnCl}_{4}, \mathrm{SbCl}_{5}$ [82]. In addition, are used double and triple complex systems of catalysts, such as $\mathrm{FeCl}_{3}$ with nitrogencontaining electron-donating compounds and compounds that inhibit the free radical reactions of chlorination, leading to the formation of by-products trichloroethane, ethyl chloride and other $[1,2]$.

The scheme of 1,2-dichloroethane (DCE) is obtained by the oxidation and direct chlorination of ethylene by the addition of chlorine by double bonding of ethylene.

$$
\begin{gathered}
\mathrm{CH}_{2}=\mathrm{CH}_{2}+\mathrm{CI}_{2} \square \mathrm{CH}_{2} \mathrm{CI}-\mathrm{CH}_{2} \mathrm{CI} \\
\mathrm{FeCI}_{3}+\mathrm{CI}_{2} \square \mathrm{FeCI}^{+}+\mathrm{CI}^{-} \\
\mathrm{FeCI}_{4}{ }^{+}+\mathrm{CI}^{-}+\mathrm{CH}_{2}=\mathrm{CH}_{2} \square \mathrm{CICH}_{2}-\mathrm{CH}_{2} \mathrm{CI}+\mathrm{FeCI}_{3}
\end{gathered}
$$

Many patents are dedicated to the use of a mixture of ferric chlorides and a mixture of chlorides of alkali or alkaline earth metals or ammonium. Such mixtures in the environment of dichloroethane form among themselves tetrachlorates such as $\mathrm{NaFeCl}_{4}$,
$\mathrm{KFeCl}_{4}, \quad \mathrm{Mg}\left(\mathrm{FeCl}_{4}\right)_{2}, \quad \mathrm{NH}_{4} \mathrm{FeCl}_{4}$ [2], which are excellent selective catalysts for the main process and simultaneously inhibitors of adverse reactions. It is known that at a concentration of sodium chloride and chlorine iron in a molar ratio of $0.3-0.5$, it is possible to achieve a purity of DCE (99.94\%), at which it is possible not to carry out its additional purification from by-products [3, 4].

In [5], the following model of dichloroethane formation during the interaction of ethylene and chlorine in a liquid dichloroethane environment is proposed. Chlorine and ethylene are separately dissolved in dichloroethane, the reaction proceeds in a liquid phase. The reaction is assumed to occur instantaneously. Since the solubility of chlorine in DCE is about seven times higher than the solubility of ethylene, and their diffusion coefficients are approximately equal, it is assumed that the reaction takes place near the surface of ethylene bubbles, and the bulk of the solution contains a constant concentration of free chlorine.

The smallest amount of by-product 1,1,2trichloroethane $(0.32-0.02 \%)$ is formed during use of a triple mixture of catalysts, such as $\mathrm{NaCl}+\mathrm{FeCl}_{3}$ + o-cresol, $\mathrm{CuCl}_{2}+\mathrm{FeCl}_{3}+$ o-cresol, $\mathrm{NaCl}+\mathrm{FeCl}_{3}+$ 
phenol, with the amount of o-cresol or phenol not exceeding 0.9-1.1\%, the purity of the obtained DCE is the highest $-99.68-99.98 \%$ [5].

The literature describes the effect of the dispersion of catalyst chloride salts on the kinetics and catalysis of the ethylene direct chlorination process, a method of catalyst preparation that is very interesting not only from the point of view of scientific research, but also practical application in the industrial process, but it should be noted that the complex of ferric chloride and sodium chloride is unstable and decomposes at low (less than $60^{\circ} \mathrm{C}$ ) temperatures. Therefore, catalyst systems modifiers must be used to stabilize the catalytic converter complex.

Considering the experience of other researchers who have used as a stabilizer the catalytic complex of compounds with nitrogen-containing donors, such as hexamethyl-phosphorriamide, pyridine and radical-inhibitors of 2,6-di-tert-butyl-4methyl-phenol, n-nitro-phenol, n 2,2-di (noxyphenyl) propane [6], [7] in chlorination reactions as well as in oxidation reactions of organic compounds [8], we researched the effect of such a catalyst complex stabilizer as the sodium salt of perfluoro sulfonic acid of the general formula $\left(\left(\mathrm{CF}_{3} \mathrm{CF}_{2} \mathrm{OCF}_{2} \mathrm{CF}\left(\mathrm{CF}_{3}\right) \mathrm{OCF}_{2} \mathrm{CF}_{2} \mathrm{SO}_{3} \quad \mathrm{Na}\right)\right.$ in an amount of 1-10\% mas. of sodium chloride.

Aim of research: to research the effect of the sodium salt of perfluoro sulfate on the catalytic activity of the iron-sodium catalyst and the selectivity of the formation of 1,2-dichloroethane in the reaction of direct chlorination of ethylene and to propose a method of preparation of the catalyst for this process.

\section{Materials and methods of research}

The objects of study were chlorides of iron and sodium, promoted by the sodium salt of perfumed sulfuric acid, as catalysts for the direct chlorination process of ethylene.

The ethylene direct chlorination catalyst was prepared in a 800 liter capacity tank equipped with a stirring circulation pump. Dry anhydrous $\mathrm{FeCl}_{3}$ (99\%) was dissolved in anhydrous 1,2-DCE $(99.975 \%)$ in an amount of $5 \mathrm{~kg}$, which corresponds to its concentration in the tank for the preparation of a catalyst of about $7200 \mathrm{ppm}$ (or 1000ppm (0.01\%) in a chlorine reactor - At a temperature of $60-80^{\circ} \mathrm{C}$ with vigorous stirring with a circulating pump for 12 hours before the formation of a homogeneous solution.

Prepared for dissolution of sodium chloride with sodium salt of perfluoro-sulphonic acid in the amount of $1.5 \mathrm{~kg}$ with concentrations of the last 1$10 \%$, which corresponds to the concentration of sodium ions $2160 \mathrm{ppm}$ in the tank for the preparation of the catalyst (or $100 \mathrm{ppm}(0,001 \%)$ in the reactor direct chlorination), backfilled in a container where the $\mathrm{FeCl}_{3}$ catalyst was previously dissolved. The dissolution of a mixture of sodium chloride and sodium salt of perfluoro sulfate is carried out at a temperature of $60-80^{\circ} \mathrm{C}$ for $2 \mathrm{~h}$ with vigorous stirring until a yellow-brown dispersion is formed in DCE.

The experiments were carried out at the industrial reactor of direct chlorination of ethylene of the production of vinyl chloride of LLC "KARPATNAFTOKHM" according to the approved plan of tests of stabilizers of catalyst system [ $\left.\mathrm{NaFeCl}_{4}\right]$. The volume of the reactor is $100 \mathrm{~m}^{3}$, the degree of filling with liquid dichloroethane is $70 \%$. The analysis of chlorination products (dichloro-ethane and trichloethane) was performed chromatographically, and the content of iron and sodium ions was volatile metric according to the approved and valid methods of LLC "KARPATNAFTOKHM" [9].

\section{Results and discussion}

The results show that the complete dissolution of sodium chloride in the reactor for a catalytic solution preparation, without additives, takes place around 2 hours. The addition into the composition of the catalyst sodium salt of perfluoro sulfate in the amount of $1-4 \%$ by weight of sodium chloride does not lead to any noticeable changes in the dissolution process, and increasing the amount of stabilizer of the catalytic complex from 4 to $10 \%$ reduces the dissolution time from $2 \mathrm{~h}$ to $1 \mathrm{~h}$, moreover, the concentration of sodium ions in the catalyst solution increases for $1 \mathrm{~h}$, starting with $4 \%$ of the stabilizer content and then remains practically unchanged (table 1). 
The dependence of the content of sodium ions on the concentration of the stabilizer and the time of dissolution

\begin{tabular}{|c|c|c|c|}
\hline № & $\begin{array}{c}\text { Concentration of the } \\
\text { stabilizer, \% mas. }\end{array}$ & $\begin{array}{c}\text { The concentration of sodium ions in the tank for } \\
\text { the preparation of the catalyst, } \mathrm{ppm}\end{array}$ & $\begin{array}{c}\text { The time of dissolution, } \\
\text { hours }\end{array}$ \\
\hline 1 & 0 & 2100 & 2 \\
\hline 2 & 1 & 2120 & 2 \\
\hline 3 & 1 & 1200 & 1 \\
\hline 4 & 2 & 1220 & 1 \\
\hline 5 & 3 & 1280 & 1 \\
\hline 6 & 4 & 1670 & 1 \\
\hline 7 & 5 & 2050 & 1 \\
\hline 8 & 6 & 2120 & 1 \\
\hline 9 & 7 & 2130 & 1 \\
\hline 10 & 8 & 2150 & 1 \\
\hline 11 & 9 & 2160 & 1 \\
\hline 12 & 10 & 2130 & 1 \\
\hline
\end{tabular}

It should be noted that in the process of dissolution of sodium chloride in 1,2-dichloroethane in the presence of a stabilizer, the dispersion of sodium chloride does not play a significant role, as described in [10]. Thus, in our experiments, sodium chloride with an average particle size of $20-30 \%$ larger than in [10-13] was used.

Thus, for the preparation of the catalytic system of the process of direct chlorination of ethlene, the optimal conditions are: the time of dissolution of sodium chloride in the presence of the sodium salt of perfluoroacetic acid is $1 \mathrm{~h}$ with a content of the last 8 $10 \%$ wt. Thus obtained, a catalytic solution of iron and sodium chlorides, stabilized with sodium salt of perfluoro sulfonic acid, was fed into the reactor direct chlorination of ethylene.

The reaction products, 1,2-dichloroethane and trichloroethane, were analyzed chromatographically. As a basis for comparison of the influence of the sodium salt of the perfluoro sulfate used the average performance of the reactor of direct chlorination of ethylene in the first half of 2019, and experiments on the influence of the stabilizer was carried out in August-September 2019.

As shown by the results of long-term stabilizer tests since the beginning of the tests, the concentration of sodium ions in the direct chlorination reactor increased when it was fed to the direct chlorination reactors from $8-15 \mathrm{ppm}$ to $35-50 \mathrm{ppm}$ (ie to design values) for 5-7 days, which is due with a large circulation volume of 1,2-dichloroethane in the reaction system, which is 2-4 times larger than the volume of the chlorination reactor, and decreased after discontinuation of its dosage for 2-3 days. The results of the operation of the reactor of direct chlorination of ethylene for 2 months of operation are shown in Fig. 1.

Analysis of the TCE content showed that, as a result of using the catalyst system stabilizer, in July - August 2019, its concentration decreased in dichloroethane in direct chlorination rectors from $0.89 \%$ to $0.54 \%$ (1.6 times). Similarly, in DCE with V1201 A/B (product supplied to the rectification stage and, ultimately, the pyrolysis furnace) - from $0.49 \%$ to $0.27 \%$ ( 1.8 times).

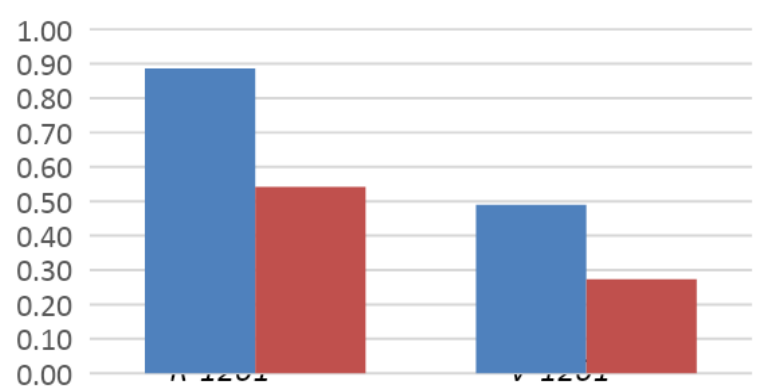

Fig.e 1. The dependence of trichloroethane content in 1,2-dichloroethane in the direct chlorination reactor $(R-1201)$ and in the storage tank before rectification $(V-1201)$ to (blue) and during the tests (red) of the catalyst system stabilizer 
Stabilizer for the catalytic system of the direct chlorine processing of ethylene to 1,2-dichlorethane

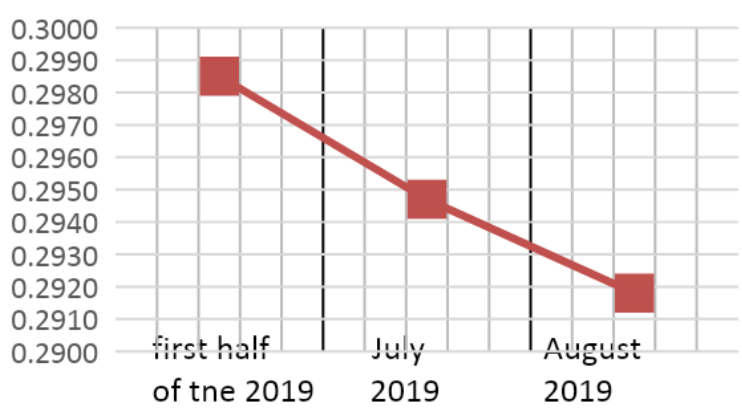

Fig. 2. Effect of catalyst system stabilizer on ethylene consumption

Analysis of the material balance of ethylene consumption at the stage of direct chlorination of ethylene compared to the period of operation without the use of activator shows a decrease in the specific consumption of ethylene by 1 ton of produced DCE (Fig. 2), which allows to save ethylene for the production of DCE.

\section{Conclusions}

1. The results of the tests of the stabilizer (a mixture of finely divided sodium chloride $90 \%$ and sodium salt of perfluoro sulfonic acid 1-10 \%) showed that the introduction of the stabilizer allowed to achieve the desired concentration of sodium ions (35-50 ppm) in the reactors of direct chlorination.

2. The optimal concentration of the sodium salt of the perfluorinated sulfoxide lot is determined, in which dissolution of sodium chloride occurs within $1 \mathrm{~h}$ while maintaining the catalytic activity of the catalyst. The method of preparation of the catalyst is proposed.

3. The quality of DHE has increased throughout the test period. The content of TCE in dichloroethane decreased from $0.89 \%$ to $0.54 \%$ or 1.6 times.

\section{References}

1. Treger. Yu. A. \& Guzhnovskaya. T. D. (1989). Intensifikatsiya khlororganicheskikh proiz-vodstv. Vysokoeff-ektivnyye kataliticheskiye sistemy. Moskva: Khimiya.
2. Sterlitamak. (1969). Razrabotka i usovershenstvovanie tehnologicheskih himicheskih proizvodstv. p.154-155.

3. Patent. FRG \# 3347153.

4. SvItoviy patent \#94/17019, Pat. \#4302177 (FRG), Pat. \#4318609 (FRG), Pat. \#4425872 (FRG), Evrop. Pat. \#06815663, Evrop. pat. \# 0772576.

5. Balasubramanian, S. N., Rihami, D. N., \& Doraiswamy, L. K. (1966). Industr. and Eng. Chem. Fundament, 5, 2, 184.

6. Avetyan , M. G., \& Sonin , E. V. (1991). Issledovanie protsessa pryamogo hlorirovaniya etilena $\mathrm{v}$ promyishlennyih usloviyah. Himicheskaya Promyishlennost, 12, 710-713.

7. Bodrikov I.V., Bolshakova L.V., Groshev G.L., i dr. (1993) Patent Rossii \#2071461

8. Reutskyi V.V. (2005). Ctvorennia selektyvnykh katalitychnykh system dlia protsesiv ridynnofaznoho okysnennia vuhlevodniv. (Dys. kand. tekhn. nauk). Natsionalnyi universytet "Lvivska politekhnika", Lviv.

9. Postiinyi tekhnolohichnyi rehlament tsekhu po vyrobnytstvu vinilkhlorydu. Vyk. "Fridrikh Ude" i AT "Khiminterinzhenirinh" V-35/95. - Kalush, 1991-1995. $560 \mathrm{~s}$.

10. Kurta, S. A., Mykytyn, I. M., Khatsevich, O. M., \& Ribun, V. S. (2018). Mechanism of Catalytic Additive Chlorination of Ethylene to 1,2-Dichloroethane. Theoretical and Experimental Chemistry, 54(4), 283-291. doi: 10.1007/s11237-018-9574-6

11. Kurta, S. (2012). Catalysis of Ethylene Oxychlorination into 1,2-Dichlorethane in the Presence of $\mathrm{CuCl} 2 / \mathrm{CuCl}$ Active Centres on the Surface of (C)A12O3. Chemistry \& Chemical Technology, 6(1), 1-8.

doi: 10.23939/chcht06.01.001

12. Kurta, S. A., Haber, M. V., \& Mykytyn, I. M. (2003). The solubility of the industrial catalyst for the direct chlorination process of ethylene and the effect of its content on the quality of 1,2-dichloroethane. Chemical Industry of Ukraine, 6, 33-38.

13. Kurta, S. A., Mykytyn, I. M., \& Tatarchuk, T. R. (2014). Structure and the catalysis mechanism of oxidative chlorination in nanostructural layers of a surface of alumina. Nanoscale Research Letters, 9(1). doi: 10.1186/1556-276x-9-357 
М. В. Шпарій, В. Л. Старчевський, В. В. Реутський, Ю. М. Гринчук

Національний університет "Львівська політехніка",

Кафедра фізичної, аналітичної та загальної хімії

e-mail: vstarchevskyy@gmail.com

\section{СТАБІЛІЗАТОР ДЛЯ КАТАЛІТИЧНОЇ СИСТЕМИ ПРОЦЕСУ ПРЯМОГО ХЛОРУВАННЯ ЕТИЛЕНУ ДО 1,2-ДИХЛОРЕТАНУ}

Стаття присвячена дослідженню впливу натрісвої солі перфторсульфонової кислоти як стабілізатора на каталітичну активність хлориду заліза та хлориду натрію в реакції прямого хлорування етилену до 1,2-дихлоретану. Під час досліджень автори встановили, що підвищення концентрації стабілізатора до 4\% мас. не мав істотного впливу на каталітичну активність комплексу, але збільшення від 4\% мас. до $10 \%$ мас. дозволило скоротити час розчинення хлориду натрію та досягти необхідної концентрації іонів натрію в реакторі прямого хлорування. 3 концентрацісю дослідницького стабілізатора чистота утвореного дихлоретану збільшується, а кількість побічного продукту - трихлоретану зменшується.

Ключові слова: пряме хлорування, етилен, 1,2-дихлоретан, перфторсульфонова кислота, стабілізатор. 